Artikel Penelitian

\title{
Uji Aktivitas Antibakteri Sediaan Gel Ekstrak Etanol Pegagan (Centela Asiatica L.) Terhadap Bakteri Staphylococcus Aureus Secara In Vitro
}

\author{
Iif Hanifa Nurrosyidah ${ }^{1}$, Retna Hermawati, Milu Asri ${ }^{1}$ \\ ${ }^{1)}$ Program Studi DIII Farmasi STIKES Rumah Sakit Anwar Medika, Indonesia \\ Email: iifhanifanurrosyidah@gmail.com , Telepon 082141258831
}

\begin{abstract}
Abstrak: Staphylococcus aureus adalah bakteri patogen pada manusia yang menyebabkan berbagai manifestasi klinis. Infeksi sering terjadi baik di lingkungan yang didapat masyarakat maupun yang didapat di rumah sakit dan pengobatan tetap sulit untuk dikelola karena munculnya strain yang resistan terhadap beberapa obat seperti MRSA. Salah satu manifestasi klinis akibat infeksi bakteri tyersebut adalah bisul, kulit melepuh, dan jerawat. Jerawat merupkan salah satu masalah kesehatan kulit yang menggangu. Tingkat keparahan jerawat dipengaruhi oleh banyak faktor salah satunya dipengaruhi oleh jumlah produksi kelenjar minyak. Minyak, kotoran atau debu, dan keringat dapat menyumbat pori serta adanya bakteri penyebab jerawat (P. acne) dapat menimbulkan jerawat. Pegagan (Centella asiatica (L.) Urban) merupakan tanaman liar yang berpotensi sebagai tanaman obat. Centella asiatica L. mengandung senyawa glikosida saponin yang diketahui memiliki aktivitas sebagai antibakteri. Penelitian ini diawali dengan proses ekstraksi kandungan centolloid dari pegagan dengan diekstraksi dengan etanol 96\% menggunakan alat soxhlet pada suhu $60-80^{\circ} \mathrm{C}$. Kemudian ekstrak yang diperoleh dipekatkan menggunakan rotary evaporator pada suhu $60^{\circ} \mathrm{C}$ sampai diperoleh ekstrak kental. Ekstrak yang diperoleh diformulasikan ke dalam sediaan gel kemudian diuji aktivitas antibakterinya secara in vitro mengunakan metode difusi agar. Sediaan gel ekstrak etanol pegagan stabil hingga penyimpanan dalam jangka waktu 30 hari terlihat dari organoleptis, $\mathrm{pH}$, homogenitas, dan daya sebar yang tidak berubah dari awal pembuatan. Daya hambat sediaan gel ekstrak etanol pegagan adalah $25 \mathrm{~mm}$ termasuk dalam katagori daya hambat kuat yaitu $>20 \mathrm{~mm}$, sama dengan daya hambat kontrol positif dalam penelitian ini yaitu clindamicyn sebesar $30 \mathrm{~mm}$.
\end{abstract}

\section{Kata kunci : Pegagan, Centella asiatica, Staphylococcus aureus}

Abstract: Staphylococcus aureus is a pathogen bacterial in humans that causes various clinical manifestations. Infections often occur in both the environment by the community and in hospitals and health center. Those remain difficult to manage because of the strain problems with some drugs such as MRSA. One of the clinical manifestations due to bacterial infection are boils, blisters, and pimples. Acne is an annoying skin health problem. The severity of acne is very large. oil, dirt or dust, and sweat are able to clog pores and the presence of acne-causing bacteria (P. acne) can cause acne. Gotu kola (Centella asiatica (L.) Urban) is a wild plant that acts as a medicinal plant. Centella asiatica L. contains saponin glycoside compounds which are known to have antibacterial activity. The research began with the process of extracting centolloid content from gotu 


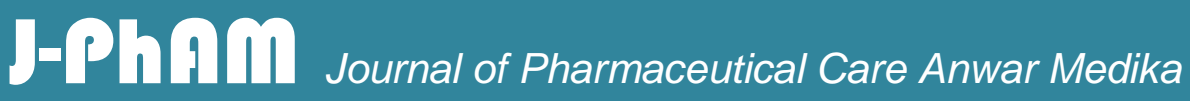

kola by extracting $96 \%$ ethanol using a soxhlet at $60^{\circ}-80^{\circ} \mathrm{C}$. Then the extract obtained was concentrated using a rotary evaporator at $60^{\circ} \mathrm{C}$ until a thick extract was obtained. The extract obtained was formulated into a preparation gel and then collected in vitro antibacterial activity using Agar diffusion method. Gotu kola ethanol extract gel was stable in storage within 30 days, it was seen from organoleptic, $\mathrm{pH}$, homogeneity, and dispersal that did not change from the beginning of manufacture. Inhibition of gotu kola extract ethanol extract is $25 \mathrm{~m}$. It is included in the category of strong inhibition that is > $20 \mathrm{~mm}$, the same as the positive control inhibition in this study is clindamicyn of $30 \mathrm{~mm}$.

\section{Keywords: Gotu kola, Centella asiatica, Staphylococcus aureus}

\section{PENDAHULUAN}

Staphylococcus aureus adalah bakteri patogen pada manusia yang menyebabkan berbagai manifestasi klinis (Rasigade, 2014). Infeksi sering terjadi baik di lingkungan yang didapat masyarakat maupun yang didapat di rumah sakit dan pengobatan tetap sulit untuk dikelola karena munculnya strain yang resistan terhadap beberapa obat seperti MRSA. Salah satu manifestasi klinis akibat infeksi bakteri S.aureus adalah bisul, kulit melepuh, dan jerawat.

Jerawat merupkan salah satu masalah kesehatan kulit yang menggangu. Jerawat pada umumnya dialami oleh kaum remaja, namun jerawat juga bisa dialami usia dewasa dan jenis kelamin baik pria maupun wanita. Secara klinis jerawat bermacam-macam, mulai dari jerawat kecil tanpa peradangan atau komedo sampai jerawat kistik (besar dan keras). Tingkat keparahan jerawat dipengaruhi oleh banyak faktor salah satunya dipengaruhi oleh jumlah produksi kelenjar minyak. Minyak, kotoran atau debu, dan keringat dapat menyumbat pori serta adanya bakteri penyebab jerawat, salah satunya yaitu bakteri $S$. aureus.

Pegagan (Centella asiatica (L.) Urban) merupakan tanaman liar yang berpotensi sebagai tanaman obat. Winarto dan Surbakti (2003) melaporkan pegagan telah ditetapkan sebagai tanaman obat tradisional sejak tahun 1884. Obat tradisional adalah obat-obatan yang diolah secara tradisional, turuntemurun, berdasarkan resep nenek-moyang, adatistiadat, kepercayaan, atau kebiasaan setempat, baik bersifat magic maupun pengetahuan tradisional (LIPI 2016). Pegagan tidak terlalu menyebabkan efek samping karena dapat dicerna oleh tubuh dan toksisitasnya rendah (Rusmiati 2007). 


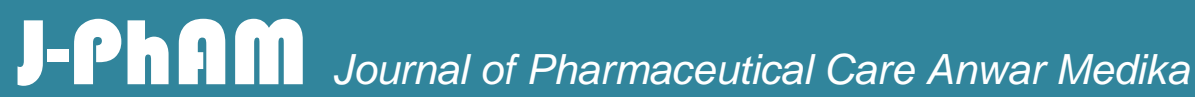

\section{Artikel Penelitian}

Centella asiatica mengandung senyawa glikosida saponin yang memiliki gugus aglikon triterpenoid pentasiklik, secara kolektif dikenal sebagai centelloids. Terpenoid ini termasuk asiatikosida, centelosida, madecassoside, brahmoside, brahminoside, thankuniside, sceffoleoside, asam centellose, asiatic-, brahmic-, centellic- dan madecassic. Saponin triterpen adalah metabolit sekunder yang umum dan disintesis melalui jalur isoprenoid menghasilkan struktur triterpenoid hidrofobik (aglikon) yang mengandung gula hidrofilik rantai (glikon). Aktivitas biologis saponin telah dikaitkan dengan karakteristik tersebut. Dalam tanaman, triterpenoid Centelloid memiliki aktivitas sebagai antimikroba dan berperan memberikan perlindungan terhadap infeksi patogen (Jacinda 2009).

Penelitian Rachmawati dkk (2011) pernah melakukan penelitian terkait aktivitas antibakteri fraksi kloroform dari ekstrak etanol pegagan terhadap bakteri E.coli, P. aeruginosa dan S. Typhi dan terbukti memiliki aktivitas sebagai antibakteri terhadap bakteri tersebut. Oleh karena itu, pada penelitin ini akan dilakukan uji aktivitas sediaan gel anti bakteri ekstrak etanol pegagan terhadap bakteri S.aureus in vitro. Kandungan senyawa centelloid pada ekstrak pegagan diharapkan mampu memiliki aktivitas anti bakteri S.aureus.

Penelitian ini diawali dengan ekstraksi simplisia pegagan dengan etanol $96 \%$ menggunakan alat soxhlet pada suhu $60-80^{\circ} \mathrm{C}$. Kemudian ekstrak yang diperoleh dipekatkan menggunakan rotary evaporator pada suhu $60^{\circ} \mathrm{C}$ sampai diperoleh ekstrak kental. Ekstrak yang diperoleh diformulasikan ke dalam sediaan gel kemudian diuji aktivitas antibakterinya secara in vitro mengunakan metode difusi agar.

\section{METODE PENELITIAN}

\section{Alat}

Alat yang digunakan adalah oven pengeringan (memert@), blender (Miyako®), timbangan analitik (Ohaus $\left.{ }^{\circledR}\right)$ dan alat-alat gelas (pyrex®), Bahan yang digunakan adalah DMSO, etanol 96\%, Simplisia pegagan, CMC Na, Carbomer 940, gliserin, propilen glikol, metil paraben, korigen odoris, aquadem. 


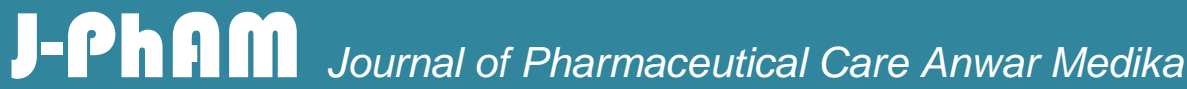

Artikel Penelitian

\section{PROSEDUR PENELITIAN}

\section{Pembuatan Ekstrak Etanol Pegagan}

Pembuatan ekstrak pada penelitian ini dilakukan dengan menyari serbuk pegagan menggunakan metode sokletasi. Serbuk pegagan sebanyak 400 gram dibagi menjadi 4 bagian yang sama banyak, proses sokletasi dilakukan sebanyak 4 kali. Serbuk pegagan diekstraksi dengan etanol $96 \%$ menggunakan alat soxhlet pada suhu $60-80^{\circ} \mathrm{C}$ kemudian ditunggu hingga zat aktif dalam simplisia tersari seluruhnya yang ditandai dengan jernihnya cairan yang lewat pada tabung sifron. cairan yang diperoleh dari 4 kali sokletasi selanjutnya diuapkan dengan rotary evaporator pada suhu $60^{\circ} \mathrm{C}$ sampai diperoleh ekstrak kental. Ekstrak etanol pegagan yang diperoleh kemudian dikumpulkan dan diukur bobotnya untuk menghitung rendemen yang dihasilkan (Rachmawati, 2011).

\section{Skrining Fitokimia Ekstrak Pegagan}

\section{Lignin}

Buat sediaan dalam media kloralhidrat, tsmbshksn florogusin-HCl. Dinding sel yang mengandung lignin akan berwarna merah.

\section{Suberin, Kutin, Minyak Lemak, dan Minyak atsiri}

Buat sediaan dalam media air, tambahkan Sudan III. Bagian serbuk simplisia yang mengandung suberin, kutin, minyak lemak atau minyak atsiri berwarna jingga.

\section{Amilum dan Aleuron}

Buat sediaan dalam media air, tambahkan beberapa tetes Iodium 0,1 N. Serbuk yang mengandung amilum berwarna biru, sedangkan yang mengandung aleuron akan berwarna kuning coklat sampai coklat.

\section{Tanin/ Zat samak}

Pada bahan simplisia dalam air, tambahkan berapa tetes $\mathrm{FeCl} 3$, serbuk yang mengandung tanin berwarna hijau, biru sampai hitam.Turunan Katekol

Pada bahan simplisa dalam media air, tambahkan larutan vanillin 10\% dalam etanol $90 \%$ dan tambahkan HCl P. Serbuk yang mengandung turunan katekol berwarna merah intensif. 


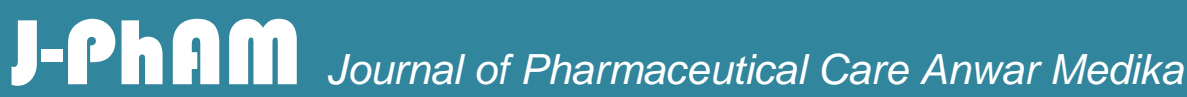

Artikel Penelitian

\section{1,8 Dioksiantrakinon Bebas}

Pada baan simplisia dakam media air, tambahkan larutan bouchartdat. Serbuk yang mengandung alkaloid berwarna merah coklat sampai hitam.

\section{Alkaloid}

Pada bahan simplisa dalam air, tambahkan larutann bouchardat. Serbuk yang mengandung alkaloid berwarna merah coklat sampai hitam.

\section{Flavonoid}

Pada bahan simplisia dalam air, tambahkan ammoniak 25\%. Serbuk yang mengandung flavonoid berwarna kuning kehijauan.

\section{Uji Aktivitas Antibakteri Ekstrak Etanol Pegagan}

Larutan uji dibuat dengan lima seri konsentrasi yaitu 200 mg/mL, 100 mg/mL, 50 $\mathrm{mg} / \mathrm{mL}, 25 \mathrm{mg} / \mathrm{ml}$ kemudian dilarutkan dengan pelarut dimetilsulfoksida (DMSO). Aktivitas antibakteri diuji dengan metode difusi agar. Larutan uji sebanyak $10 \mu$ diteteskan diatas paperdisk (diameter $=6 \mathrm{~mm}$ ) kemudian dibiarkan hingga mengering. Suspensi bakteri sebanyak $200 \mu \mathrm{l}$ dicampur dengan $20 \mathrm{ml}$ media nutrient agar (dalam keadaan hangat), digojog supaya homogen kemudian dituang ke dalam cawan petri. Ditunggu beberapa saat hingga media membeku. Paperdisk yang mengandung larutan uji kemudian diletakkan di atas permukaan media agar, dan diinkubasi pada suhu 37oC selama 18-24 jam. Kontrol positif menggunakan antibiotik ciprofloxacin $10 \mu \mathrm{g} /$ disk dan kontrol negatif digunakan paperdisk yang telah ditetesi pelarut DMSO.

\section{Pembuatan Sediaan Gel Ekstrak Etanol Pegagan}

Pembuatan sediaan gel anti jerawat ekstrak pegagan diawali dengan membuat basis gel dengan cara menaburkan basis gel (CMC-Na) ke dalam air panas dan ditungu hingga mengembang lalu dicampur dengan ekstrak pegagan yang sebeumnya sudah dilarutkan air panas sedikit demi sedikit sampai homogen sambil ditambahkan bahan yang lainnya sedikit demi sedikit sampai homogen. Penelitian ini membuat empat formulasi sediaan gel seperti yang dapat dilihat pada tabel 1 bawah ini: 


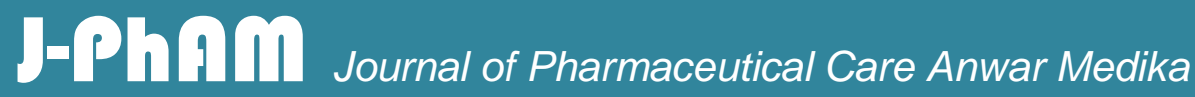

Artikel Penelitian

Tabel 1 Formulasi Sediaan Gel Ekstrak Etanol Pegagan (Centella asiatica L.)

\begin{tabular}{|c|c|c|c|c|c|}
\hline \multirow[t]{2}{*}{ No } & \multirow[t]{2}{*}{ Bahan } & \multicolumn{4}{|c|}{ Jumlah (gram) } \\
\hline & & $\mathrm{F} 1$ & $\mathrm{~F} 2$ & F3 & $\mathrm{F} 4$ \\
\hline 1 & Ekstrak pegagan & 0,5 & 2,5 & 5 & 0 \\
\hline 2 & $\mathrm{CMC}-\mathrm{Na}$ & 4,5 & 4 & 3,5 & 3 \\
\hline 3 & Carbomer 940 & 0,5 & 1 & 1,5 & 2 \\
\hline 4 & Gliserin & 1 & 1 & 1 & 1 \\
\hline 5 & Propilen glikol & 5 & 5 & 5 & 5 \\
\hline 6 & Metil Paraben & 0,2 & 0,2 & 0,2 & 0,2 \\
\hline 7 & Corrigen odoris & qs & qs & qs & qs \\
\hline 8 & Aquadem & Ad 100 & Ad 100 & Ad 100 & Ad 100 \\
\hline
\end{tabular}

Sumber : Data primer, 2019

\section{Evaluasi Fisik Sediaan Gel Ekstrak Etanol Pegagan}

Evaluasi sediaan dilakukan dengan mengamati karakteristik fisika yang meliputi organoleptis, homogenitas, $\mathrm{pH}$, dan daya sebar. Uji stabilitas dilakukan pada hari pertama, ke 15 dan ke 30 (Shu, 2013).

\section{HASIL DAN PEMBAHASAN}

Hasil Skrining Fitokimia Ekstrak Etanol Pegagan dapat dilihat pada Tabel 2.

Tabel 2. Skrining Fitokimia Ekstrak Etanol Pegagan ( Centella asiatica )

\section{Uji Fitokimia Ekstrak Etanol Pegagan}

\begin{tabular}{cc}
\hline Minyak Atsiri & + \\
Tanin & + \\
Alkaloid & + \\
Flavonoid & + \\
Glikosida & + \\
\hline
\end{tabular}

Sumber : Data primer, 2019

Berdasarkan uji histokimia pegagan positif mengandung glikosida. Menerut literartur bahwa pegagan mengandung glikosida asiatikosida, tankunisida, isotankunisida, madekasosida, brahmosida, brahminosida dan sentelosida. 


\section{Artikel Penelitian}

Pegagan positif mengandung tanin, alkaloid dan minyak atsiri sesuai pustaka yang menyatakan bahwa pegagan mengandung asam brahmik, asam madasiatik, mesoinositol, karotenoid, idrokotilin, vellarin, tanin serta garam mineral seperti kalium, natrium, magnesium, kalsium, dan besi (Musyarofah et al. 2004), fosfor, minyak atsiri (1\%), pektin (17.25\%), zat pahit vellarine (alkaloid), dan zat samak (Dalimartha 2006).

Tanaman pegagan mengandung asiatikosida berupa glikosida dan banyak digunakan dalam ramuan obat tradisional atau jamu. Asiatikosida, asam asiatik, madekasida, dan madekasosida termasuk golongan triterpenoid, sementara sitosterol dan stigmasterol termasuk golongan steroid serta vallerin brahmosida golongan saponin. Asiatikosida merupakan glikosida triterpen, derivat alfaamarin dengan molekul gula yang terdiri atas dua glukosa dan satu rhamnosa. Aglikon triterpen pada pegagan disebut asiatikosida yang mempunyai gugus alkohol primer, glikol, dan satu karboksilat teresterifikasi dengan gugus gula.

Menurut Winarto dan Surbakti (2003), pegagan mengandung berbagai bahan aktif, yaitu: 1) triterpenoid saponin, 2) triterpenoid genin, 3) minyak atsiri, 4) flavonoid, 5) fitosterol, dan bahan aktif lainnya. Kandungan bahan aktif yang terpenting adalah triterpenoid dan saponin, yang meliputi: 1) asiatikosida, 2) sentelosida, 3) madekosida, dan 4) asam asiatik serta komponen lain seperti minyak volatil, flavonoid, tanin, fitosterol, asam amino, dan karbohidrat. Semua kandungan bioaktif tanaman pegagan merupakan antioksidan yang bermanfaat bagi tubuh manusia dalam meningkatkan sistem imun. Kandungan zat aktif dalam tanaman pegagan dipengaruhi oleh banyak faktor di antaranya adalah letak geografis, usia panen, dan pengolahan paska panen.

Hasil Uji Antibakteri Ekstrak Etanol Pegagan dapat dilihat pada Tabel 3. Menunjukkan bahwa ekstrak pegagan memiliki aktivitas antibakteri terhadap S.aureus dengan daya hambat lemah yaitu pada kisaran 10-15 mm pada konsentrasi ekstrak 2,5\% dan 5\%(Greenwood, 1995). Daya hambat kontrol positif lebih besar yaitu $25 \mathrm{~mm}$ (daya hambat kuat) (Greenwood, 1995).

Ekstrak etanol pegagan mengandung senyawa minyak atsiri yang memiliki aktivitas sebagai antibakteri (Rahmawati, 2011). 


\section{Artikel Penelitian}

Tabel 3. Uji Antibakteri Ekstrak Etanol Pegagan ( Centella asiatica)

\section{Konsentrasi Ekstrak}

Zona Hambat Terhadap

S.aureus

\begin{tabular}{|c|c|}
\hline \multicolumn{2}{|l|}{$0,5 \%$} \\
\hline $\mathrm{R} 1$ & $5 \mathrm{~mm}$ \\
\hline $\mathrm{R} 2$ & $5 \mathrm{~mm}$ \\
\hline R3 & $5 \mathrm{~mm}$ \\
\hline Rata-rata & $5 \mathrm{~mm}$ \\
\hline \multicolumn{2}{|l|}{$2.5 \%$} \\
\hline $\mathrm{R} 1$ & $15 \mathrm{~mm}$ \\
\hline $\mathrm{R} 2$ & $10 \mathrm{~mm}$ \\
\hline R3 & $20 \mathrm{~mm}$ \\
\hline Rata-rata & $15 \mathrm{~mm}$ \\
\hline \multicolumn{2}{|l|}{$5 \%$} \\
\hline $\mathrm{R} 1$ & $15 \mathrm{~mm}$ \\
\hline $\mathrm{R} 2$ & $10 \mathrm{~mm}$ \\
\hline R3 & $20 \mathrm{~mm}$ \\
\hline Rata-rata & $15 \mathrm{~mm}$ \\
\hline \multicolumn{2}{|c|}{ Kontrol (+) Clindamycin } \\
\hline \multicolumn{2}{|c|}{ R1 } \\
\hline $\mathrm{R} 2$ & $20 \mathrm{~mm}$ \\
\hline R3 & $30 \mathrm{~mm}$ \\
\hline \multirow[t]{2}{*}{ Rata-rata } & $25 \mathrm{~mm}$ \\
\hline & $25 \mathrm{~mm}$ \\
\hline \multicolumn{2}{|l|}{ Kontrol (-) } \\
\hline R1 & $0 \mathrm{~mm}$ \\
\hline $\mathrm{R} 2$ & $0 \mathrm{~mm}$ \\
\hline R3 & $0 \mathrm{~mm}$ \\
\hline Rata-rata & $0 \mathrm{~mm}$ \\
\hline \multicolumn{2}{|l|}{$0,5 \%$} \\
\hline $\mathrm{R} 1$ & $5 \mathrm{~mm}$ \\
\hline $\mathrm{R} 2$ & $5 \mathrm{~mm}$ \\
\hline R3 & $5 \mathrm{~mm}$ \\
\hline Rata-rata & $5 \mathrm{~mm}$ \\
\hline \multicolumn{2}{|l|}{$2,5 \%$} \\
\hline R1 & $15 \mathrm{~mm}$ \\
\hline $\mathrm{R} 2$ & $10 \mathrm{~mm}$ \\
\hline R3 & $20 \mathrm{~mm}$ \\
\hline Rata-rata & $15 \mathrm{~mm}$ \\
\hline \multicolumn{2}{|l|}{$5 \%$} \\
\hline R1 & $15 \mathrm{~mm}$ \\
\hline $\mathrm{R} 2$ & $10 \mathrm{~mm}$ \\
\hline R3 & $20 \mathrm{~mm}$ \\
\hline Rata-rata & $15 \mathrm{~mm}$ \\
\hline
\end{tabular}


Artikel Penelitian

$\begin{array}{cc}\text { Kontrol (+) Clindamycin } & \\ \text { R1 } & \\ \text { R2 } & 20 \mathrm{~mm} \\ \text { R3 } & 30 \mathrm{~mm} \\ \text { Rata-rata } & 25 \mathrm{~mm} \\ & 25 \mathrm{~mm}\end{array}$

Kontrol (-)

$\begin{array}{ll}\text { R1 } & 0 \mathrm{~mm} \\ \text { R2 } & 0 \mathrm{~mm} \\ \text { R3 } & 0 \mathrm{~mm} \\ \text { Rata-rata } & 0 \mathrm{~mm}\end{array}$

Sumber : Data primer, 2019

Hasil evaluasi stabilitas fisik sediaan gel ekstrak pegagan ditunjukkan pada Tabel 4.

Tabel 4 . Stabilitas Fisik Sediaan Gel kstrak Etanol Pegagan ( Centella asiatica )

\begin{tabular}{|c|c|c|c|c|}
\hline Evaluasi & F1 & F2 & F3 & F4 \\
\hline $\begin{array}{c}\text { Organoleptis } \\
\text { H-1 } \\
\text { H-15 } \\
\text { H-30 }\end{array}$ & $\begin{array}{l}\text { Sediaan gel } \\
\text { berwarna } \\
\text { coklat } \\
\text { kehijauan } \\
\text { stabil sampai } \\
\text { hari ke-30 }\end{array}$ & $\begin{array}{l}\text { Sediaan gel } \\
\text { berwarna } \\
\text { coklat stabil } \\
\text { sampai hari } \\
\text { ke-30 }\end{array}$ & $\begin{array}{l}\text { Sediaan gel } \\
\text { berwarna } \\
\text { coklat tua } \\
\text { stabil sampai } \\
\text { hari ke-30 }\end{array}$ & $\begin{array}{l}\text { Sediaan gel } \\
\text { berwarna } \\
\text { bening stabil } \\
\text { sampai hari } \\
\text { ke-30 }\end{array}$ \\
\hline \multicolumn{5}{|l|}{ Homogenitas } \\
\hline $\mathrm{H}-1$ & $\begin{array}{l}\text { Sediaan gel } \\
\text { homogen }\end{array}$ & $\begin{array}{c}\text { Sediaan gel } \\
\text { homogen }\end{array}$ & $\begin{array}{l}\text { Sediaan gel } \\
\text { homogen }\end{array}$ & $\begin{array}{c}\text { Sediaan gel } \\
\text { homogen }\end{array}$ \\
\hline $\mathrm{H}-15$ & $\begin{array}{l}\text { hingga hari } \\
\text { ke-30 }\end{array}$ & $\begin{array}{c}\text { hingga hari } \\
\text { ke-30 }\end{array}$ & $\begin{array}{c}\text { hingga hari } \\
\text { ke-30 }\end{array}$ & $\begin{array}{c}\text { hingga hari } \\
\text { ke-30 }\end{array}$ \\
\hline \multicolumn{5}{|l|}{$\mathrm{H}-30$} \\
\hline $\mathrm{H}-1$ & 6 & 5,5 & 4 & 7 \\
\hline $\mathrm{H}-15$ & 6 & 5,5 & 4 & 7 \\
\hline $\mathrm{H}-30$ & 6 & 5,5 & 4 & 7 \\
\hline \multicolumn{5}{|l|}{ Daya Sebar } \\
\hline $\mathrm{H}-1$ & 3 & 2,9 & 3 & 3 \\
\hline $\mathrm{H}-15$ & 3 & 2,9 & 3 & 3 \\
\hline $\mathrm{H}-30$ & 3 & 2,9 & 3 & 3 \\
\hline
\end{tabular}

Sumber : Data primer, 2019 


\section{Artikel Penelitian}

Sediaan gel ekstrak etanol pegagan relatif stabil selama penyimpanan pada suhu kamar $\left(25-30^{\circ} \mathrm{C}\right)$ selama 30 hari.

Hasil Uji Antibakteri Sediaan Gel Ekstrak Etanol Pegagan dapat dilihat pada Tabel 5.

Tabel 5. Uji Antibakteri Ekstrak Etanol Pegagan ( Centella asiatica)

\begin{tabular}{cc}
\hline Konsentrasi Ekstrak & Zona Hambat Terhadap \\
& \multicolumn{1}{c}{ S.aureus } \\
\hline F1 & $15 \mathrm{~mm}$ \\
R1 & $10 \mathrm{~mm}$ \\
R2 3 & $20 \mathrm{~mm}$ \\
Rata-rata & $15 \mathrm{~mm}$ \\
F2 & \\
R1 & $15 \mathrm{~mm}$ \\
R2 & $10 \mathrm{~mm}$ \\
R3 & $20 \mathrm{~mm}$ \\
Rata-rata & $15 \mathrm{~mm}$ \\
F3 & \\
R1 & $25 \mathrm{~mm}$ \\
R2 & $20 \mathrm{~mm}$ \\
R3 & $30 \mathrm{~mm}$ \\
Rata-rata & $25 \mathrm{~mm}$ \\
Kontrol (-)/ F4 & \\
R1 & $0 \mathrm{~mm}$ \\
R2 & $0 \mathrm{~mm}$ \\
R3 & $0 \mathrm{~mm}$ \\
Rata-rata & $0 \mathrm{~mm}$ \\
R1 & \\
R2 & $30 \mathrm{~mm}$ \\
R3 &
\end{tabular}

Sumber : Data primer, 2019

Sediaan gel ekstrak etanol pegagan memiliki daya hambat kuat yaitu $25 \mathrm{~mm}(>20$ mm) lebih besar dibanding dengan ekstrak etanol pegagan. Hal ini kemungkinan dikarenakan sediaan gel pada penelitian ini menggunakan carbomer 940 yang merupakan polimer hidroalkoholik yang mampu berpenetrasi ke dalam dinding sel bakteri gram positif menembus asam teikhoat dan menembus membran plasma lipid (Brady, 2017). 


\section{Artikel Penelitian}

\section{KESIMPULAN}

Berdasarkan dari hasil penelitian yang telah dilakukan dapat disimpulkan sebagai berikut:

1. Ekstrak etanol pegagan memiliki aktivitas antibakteri terhadap S.aureus dengan daya hambat lemah yaitu $15 \mathrm{~mm}$ pada konsentrasi ekstrak 2,5\% dan $5 \%$. Aktivitas antibakteri ekstrak pegagan terhadap S.aureus adalah adanya kandungan triterpenoid.

2. Sediaan gel ekstrak etanol pegagan stabil hingga penyimpanan dalam jangka waktu 30 hari terlihat dari organoleptis, $\mathrm{pH}$, homogenitas, dan daya sebar yang tidak berubah dari awal pembuatan.

Sediaan gel ekstrak etanol pegagan memiliki daya hambat kuat yaitu $25 \mathrm{~mm}(>20$

$\mathrm{mm}$ ) lebih besar dibanding dengan ekstrak etanol pegagan. Hal ini kemungkinan dikarenakan terdapat delivery system dari sediaan gel dengan basis carbomer 940 yang mampu berpenetrasi dengan baik pada peptodoglikan dinding sel bakteru S.aureus.

\section{SARAN}

Saran untuk penelitian selanjutnya adalah:

1. Melakukan uji aktivitas antibakteri terhadap bakteri lain seperti Propionibacterium acne dari sediaan gel ekstrak pegagan.

2. Melakukan evaluasi stabilitas dengan parameter lebih lengkap seperti uji daya lekat, viskositas dan kemampuan penetrasi sediaan gel.

3. Mengembangkan dalam bentuk sediaan dengan teknologi yang lebih tinggi seperti sediaan nanopartikel. 


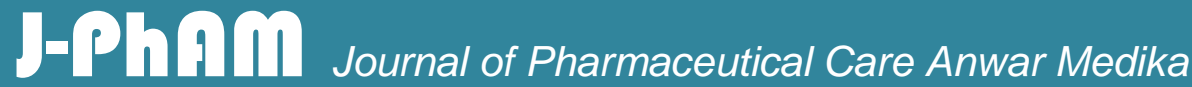

Artikel Penelitian

\section{DAFTAR PUSTAKA}

1. Brady, J., et al. Polymer properties and characterization. In: Developing solid oral dosage forms. Academic Press, 2017. p. 181-223

2. Boucher HW, Corey GR. Epidemiology of methicillin-resistan Staphylococcus aureus. Clin. Infect. Dis. 2008 Jun 01;46 Suppl 5:S344-9. [PubMed]

3. Dalimartha, S. (2006). Atlas tumbuhan indonesia. Jilid, 4, 4-13.

4. DeLeo FR, Diep BA, Otto M. Host defense and pathogenesis in Staphylococcus aureus infections. Infect. Dis. Clin. North Am. 2009 Mar;23(1):17-34. [PMC free article] PubMed]

5. Greenwood D. 1995. Antibiotics Susceptibility (Sensitivity) Test, Antimicrobial and Chemotheraphy. United State of America: Mc Graw Hill Company.

6. Hasanah, I. W. (2009). Pengaruh ektrak daun pegagan (Centella asiatica) terhadap spermatogenesis mencit (Mus musculus) (Doctoral dissertation, Universitas Islam Negeri Maulana Malik Ibrahim).

7. Jalian, H. R., Liu, P. T., Kanchanapoomi, M., Phan, J. N., Legaspi, A. J., \& Kim, J. (2008). All-trans retinoic acid shifts Propionibacterium acnes-induced matrix degradation expression profile toward matrix preservation in human monocytes. Journal of Investigative Dermatology, 128(12), 2777-2782.

8. Musyarofah, N., Susanto, S., Aziz, S. A., \& Kartosoewarno, S. (2007). Respon tanaman pegagan (Centella asiatica L. Urban) terhadap pemberian pupuk alami di bawah naungan. Jurnal Agronomi Indonesia (Indonesian Journal of Agronomy), 35(3).

9. Rachmawati, F., \& Nuria, M. C. (2011). Uji Aktivitas Antibakteri Fraksi Kloroform Ekstrak Etanol Pegagan (Centella Asiatica (L) Urb) Serta Identifikasi Senyawa Aktifnya. e-Publikasi Fakultas Farmasi, 7-13. 


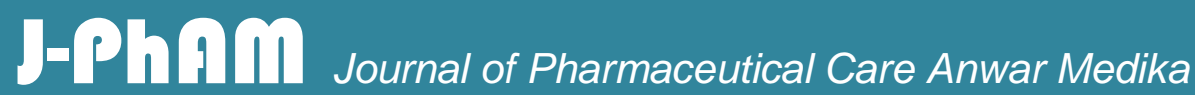

Artikel Penelitian

10. Ramadhan, N. S., Rasyid, R., \& Syamsir, E. (2015). Daya Hambat Ekstrak Daun Pegagan (Centella asiatica) yang Diambil di Batusangkar terhadap Pertumbuhan Kuman Vibrio cholerae secara In Vitro. Jurnal Kesehatan Andalas, 4(1).

11. Rasigade JP, Vandenesch F. Staphylococcus aureus: a pathogen with still unresolved issues. Infect. Genet. Evol. 2014 Jan;21:510-4. [PubMed]

12. Sinurat, A. P., Purwadaria, T., Zainuddin, D., Bermawie, N., Rizal, M., \& Raharjo, M. (2008). Utilization of plant bioactives as feed additives for laying hens. In The First Int. Symp. On Temulawak (pp. 27-29).

13. Shu, M. (2013). Formulasi sediaan gel hand Sanitizer dengan bahan aktif Triklosan 0, $5 \%$ dan 1\%. Calyptra, 2(1), 1-14.

14. Sutardi, S. (2016). Kandungan Bahan Aktif Tanaman Pegagan dan Khasiatnya untuk Meningkatkan Sistem Imun Tubuh. Jurnal Penelitian dan Pengembangan Pertanian, 35(3), 121-130.

15. Tong SY, Davis JS, Eichenberger E, Holland TL, Fowler VG. Staphylococcus aureus infections: epidemiology, pathophysiology, clinical manifestations, and management. Clin. Microbiol. Rev. 2015 Jul;28(3):603-61. [PMC free article] PubMed]

16. Winarto, W. P. Surbakti, 2003. Khasiat dan Manfaat Pegagan Tanaman Penambah Daya Ingat, 1, 5-9.

17. Vinolina, N. S. 2014. Peningkatan Produksi Centellosida pada Pegagan (Centella asiatica) Melalui Pemberian Fosfor dan Metil Jasmonat dengan Umur Panen yang Berbeda (Doctoral dissertation). 